\title{
A Tuber Lectin from Arisaema jacquemontii Blume with Anti-insect and Anti-proliferative Properties
}

\author{
Manpreet Kaur ${ }^{1}$, Kuljinder Singh', Pushpinder Jai Rup ${ }^{2}$, Sukhdev Singh Kamboj', Ajit Kumar Saxena ${ }^{3}$, \\ Madhunika Sharma ${ }^{3}$, Madhulika Bhagat ${ }^{3}$, Sarvesh Kumar Sood ${ }^{4}$ and Jatinder Singh ${ }^{1, *}$ \\ ${ }^{1}$ Department of Molecular Biology and Biochemistry, Guru Nanak Dev University, Amritsar 143 005, India \\ ${ }^{2}$ Department of Zoology, Guru Nanak Dev University, Amritsar 143 005, India \\ ${ }^{3}$ Department of Pharmacology, Regional Research Laboratory, Jammu 180 001, India \\ ${ }^{4}$ Department of Biosciences, Himachal Pradesh University, Shimla 170 001, India
}

Received 10 March 2006, Accepted 20 April 2006

\begin{abstract}
A tuber lectin from Arisaema jacquemontii Blume belonging to family Araceae was purified by employing a single step affinity chromatography using column of asialofetuinlinked amino activated silica beads and the bound lectin was eluted with $100 \mathrm{mM}$ glycine-HCl buffer $\mathrm{pH}$ 2.5. The purified $A$. jacquemontii lectin (AJL) showed a single protein band with an apparent molecular mass of $13.4 \mathrm{kDa}$ when submitted to SDS-polyacrylamide gel electrophoresis under reducing as well as non-reducing conditions. The native molecular mass of AJL determined by gel filtration on a Biogel P-200 column was $52 \mathrm{kDa}$ and its carbohydrate content was estimated to be $3.40 \%$. Thus AJL is a tetrameric glycoprotein. The purified lectin agglutinated erythrocytes from rabbit but not from human. Its activity was not inhibited by any of the mono- and disaccharides tested except $\mathrm{N}$-acetyl-D-lactosamine having minimal inhibitory sugar concentration (MIC) $25 \mathrm{mM}$. Among the glycoproteins tested only asialofetuin was found to be inhibitory (MIC $125 \mu \mathrm{g} / \mathrm{mL}$ ). A single band was obtained in native PAGE at pH 4.5 while PAGE at pH 8.3 showed two bands. Isoelectric focusing of AJL gave multiple bands in the pI range of 4.65.5. When incorporated in artificial diet AJL significantly affected the development of Bactrocera cucurbitae (Coquillett) larvae indicating the possibility of using this lectin in a biotechnological strategy for insect management of cucurbits. Larvae fed on artificial diet containing sublethal dose of AJL showed a significant decrease in acid phosphatase and alkaline phosphatase activity while esterase activity markedly increased as compared to larvae fed on diet without lectin. Out of various human cancer cell lines employed in sulphorhodamine B (SRB) assay, this
\end{abstract}

\footnotetext{
*To whom correspondence should be addressed.

Tel: 91-183-2258802-09 ext. 3313; Fax: 91-183-2258819 2258820

E-mail: jatinderarora58@rediffmail.com
}

lectin was found to have appreciable inhibitory effect on the in vitro proliferation of HCT-15, HOP-62, SW-620, HT29, IMR-32, SKOV-3, Colo-205, PC-3, HEP-2 and A-549 cancer cell lines by 82, 77, 73, 70, 41, 41, 37, 29, 21 and $21 \%$ respectively.

Keywords: Anti-cancer, Anti-insect, Araceae, Arisaema, asialofetuin, Bactrocera cucurbitae, Lectin, N-acetyl-Dlactosamine

\section{Introduction}

Structural domains that recognize and bind specific carbohydrates without altering the recognized sugars are widely distributed in all sorts of living organisms ranging from simple viruses to the most complex higher animals. Proteins possessing such carbohydrate-binding domains are usually called lectins (Candy et al., 2003). They represent a heterogenous group of oligomeric proteins varying in size, structure, molecular organization as well as their carbohydrate-binding sites. The abundance and the variety of carbohydrate specificities of lectins raised the interest to use these molecules for isolation and analysis of complex carbohydrates, cell separation and studies of cell surface architecture (Candy et al., 2003).

During the last decade there has been a growing interest in lectins which exhibit anti-proliferative activities. Vovariella volvacea lectin showed antitumor activity against sarcoma S180 cells (Lin and Chou, 1984). Grifola frondosa lectin was cytotoxic to HeLa cells (Kawagishi et al., 1990). Agaricus bisporus lectin possessed anti-proliferative activities against human colon cancer cell-line HT-29, breast cancer cell-line MCF-7 (Yu et al., 1993) and Tricholoma mongolicum lectin inhibited mouse mastocytoma P815 cells in vitro and sarcoma 
S-180 cells in vivo (Wang et al., 1997). Similarly wheat germ agglutinin (WGA), Concanavalin A (ConA) and phytohemagglutinin (PHA-L) had inhibitory dose-dependent effects on colorectal cancer cell lines (Abdullaev and Mejia, 1997). As every lectin is unique in its fine sugar specificity so a number of lectins from different sources should be checked for their anti-tumor potential against a variety of cell lines. In the present study, in vitro anti-cancer potential of a lectin from Arisaema jacquemontii was evaluated against thirteen human cancer cell lines.

Despite the large amount of information available on lectin sequence and specificity relatively less is known about their biological significance. One of the other current areas of lectin research is their use in protecting crop plants from the attack of insects and fungal pathogens. Insect pests are a major constraint to increased crop production in tropical and subtropical regions. Furthermore it is known that plant resistance to insect pests can be mediated by a range of primary metabolic products (e.g. proteases, amylase inhibitors, thionins and lectins) as well as by secondary metabolites (e.g. alkaloids, tannins and rotenoids). Among these plant defense factors there is increasing evidence that lectins provide defense against insects and other herbivores (Peumans et al., 1995; Carlini and Grossi-de-Sa, 2002). The entomotoxic activity of some lectins belonging to different sugar specificities has been well documented against some insects belonging to order Coleoptera (Peumans et al, 1995, Lepidoptera (Carlini and Grossi-de-Sa, 2002), Hemiptera (Carlini and Grossi-de-Sa, 2002) and on one species of Diptera (Eisemann et al., 1994).

Araceae, among the monocots, has been reported to be a lectin rich family as confirmed by the earlier reports on genus Alocasia, Amorphophallus, Arisaema, Gonatanthus, Arum, Colocasia and Xanthomonas (Shangary et al., 1995, Van Damme et al., 1995, Kaur et al., 2005, Kaur et al., 2006). The present study involves the purification, followed by physicochemical and biological characterization of a lectin from Arisaema jacquemontii Blume, a monocot, araceous plant growing under wild conditions. To check the role of this lectin in plant defense an insect bioassay was performed using melon fruit fly or Bactrocera cucurbitae (Coquillett) (Tephridae: Diptera) as the model insect. This fly is a serious pest of cucurbits in tropical countries and the damage may reach upto $100 \%$ of crop loss. In addition to cucurbits, this fly also affect $>80$ species of plants belonging to various families. Moreover this Dipteran has resisted conventional control measures with organic pesticides.

\section{Materials and Methods}

Cancer-cell lines. The human cancer cell lines i.e. MCF-7 (breast), SKOV-3 (ovary), SiHa (cervix), PC-3 (prostrate), SNB-78 (CNS), IMR-32 (neuroblastoma), Colo-205 (colon), HT-29 (colon), HCT15 (colon), SW-620 (colon), HEP-2 (liver), HOP-62 (lung) and A549 (lung) were procured from National Center for Cell Sciences, Pune, India. The cells were cultured in RPMI-1640 medium supplemented with $10 \%$ FCS glutamine $(2 \mathrm{mM})$, penicillin $(50 \mu \mathrm{g} /$ $\mathrm{ml})$ and streptomycin $(50 \mu \mathrm{g} / \mathrm{ml})$. The cell cultures were incubated at $37^{\circ} \mathrm{C}$ in a humidified atmosphere of $5 \% \mathrm{CO}_{2}$.

Insect cultures. The melon fruit flies were reared by the procedure described by Gupta and co-workers, 1978. The flies were provided with proteinex (Pfizer India) and 20\% sugar solution as food with pumpkin fruit, Cucurbitae moschata Dusch for oviposition. Cultures of Bactrocera cucurbitae were maintained at $25^{\circ} \mathrm{C} \pm 2^{\circ} \mathrm{C}$, photoperiod (L10 : D14) and 70-80\% relative humidity.

Chemicals and reagents. All sugars/derivatives, bovine serum albumin, ficoll-histopaque, freund's complete adjuvant, adriamycin, 5-fluorouracil, paclitaxel were procured from Sigma Chemical, Co.. Standard molecular weight markers, gel filtration markers and ampholines of $\mathrm{pI}$ range 3.5-9.5 were obtained from Amersham Pharmacia. Fetal calf serum from Sera Lab (GB) and RPMI 1640 were procured from GIBCO-BRL, and stored at $-20^{\circ} \mathrm{C}$ and $4^{\circ} \mathrm{C}$ respectively. Amino activated silica beads used were from Clifmar. Biogel P-200 for gel filtration chromatography was procured from Bio-Rad. All other chemicals were of analytical grade.

Preparation of tuber extract. The tubers of A. jacquemontii Blume growing wild in temperate regions were collected from Shimla, India. Tuber tissue was homogenized in $10 \mathrm{mM}$ phosphate buffered saline (PBS), pH 7.2 containing $0.02 \%$ sodium azide. The homogenate was kept overnight at $4^{\circ} \mathrm{C}$ and then centrifuged at $20,000 \times g$ for $20 \mathrm{~min}$. The crude extract was collected as clear supernatant.

Hemagglutination assay. Hemagglutination assay was carried out in a microtiter plate following a two-fold serial dilution method (Shangary et al., 1995). Thirty $\mu \mathrm{l}$ of the protein solution was incubated with an equal volume of $2 \%$ suspension of rabbit erythrocytes $\left(3.5 \times 10^{8}\right.$ cells $\left./ \mathrm{ml}\right)$. After $1 \mathrm{~h}$ of incubation at $37^{\circ} \mathrm{C}$ the agglutination was checked with unaided eye. The agglutination activity unit (AU) or titer was defined as the reciprocal of the last dilution that showed agglutination. The specific activity of the lectin was determined as the $\mathrm{AU}$ per milligram of protein. Erythrocyte specificity of lectin preparation was also tested using human $\mathrm{A}, \mathrm{B}, \mathrm{AB}$ and $\mathrm{O}$ blood group RBCs. The agglutination assay was carried out using both untreated and neuraminidasetreated erythrocytes.

Carbohydrate-binding specificity of AJL. To ascertain the carbohydrate binding specificity of lectin component in the crude extract, sugar inhibition assay was performed in a manner analogous to the hemagglutination test (Shangary et al., 1995). For this purpose a series of 39 sugars or their derivatives were used which included 4 pentoses: D-arabinose, L-arabinose, D-ribose and Dxylose, 20 hexoses or their derivatives: D-fructose, D-galactose, Dglucose, D-mannose, L-sorbose, L-fucose, L-rhamnose, N-acetylD-galactosamine, N-acetyl-D-glucosamine, N-acetyl-D-mannosamine, methyl- $\alpha$ - and methyl- $\beta$-D-glucopyranosides, methyl- $\alpha-D-m a n n o-$ pyranoside, sialic acid, methyl- $\alpha$ - and methyl- $\beta$-D-galactopyranosides, $\quad \beta$-phenyl-D-glucopyranoside, $\quad \mathrm{N}, \mathrm{N}^{\prime}, \mathrm{N}$ "-triacetylchitotriose, adonitol and myo-inositol, 7 disaccharides: $\beta$ gentiobiose, D-lactose, D-maltose, D-melibiose, D-trehalose, T- 
disaccharide ( $\beta$-D-galactose $1 \rightarrow 4 \mathrm{~N}$-acetyl-D-glucosamine) and $\mathrm{N}$ acetyl-D-lactosamine ( $\beta$-D-galactose $1 \rightarrow 3 \mathrm{~N}$-acetyl-D-galactosamine), 2 trisaccharides: D-melizitose and D-raffinose, 3 polysaccharides: chitin, glycogen and inulin. Three glycoproteins i.e. fetuin, asialofetuin and porcine mucin were also used. The various sugars or their derivatives were tested at a concentration of $100 \mathrm{mM}$ while polysaccharides and glycoproteins at a concentration of $4 \mathrm{mg} / \mathrm{ml}$. Each lectin was used at twice the lowest concentration causing agglutination of rabbit RBCs as determined through double dilution technique. The minimum concentration of the sugar in the final mixture that completely inhibited the lectin-induced hemagglutination was taken as minimal inhibitory sugar concentration (MIC).

Affinity chromatography. A column of asialofetuin-linked amino activated silica beads equilibrated with $10 \mathrm{mM}$ PBS was employed for the single step affinity purification of $A$. jacquemontii lectin (AJL). The column was prepared as explained elsewhere (Shangary et al., 1995). The crude extract containing $15 \mathrm{mg}$ of protein was charged onto the column $(0.8 \times 6.0 \mathrm{~cm})$ and the unbound protein was washed off with equilibration buffer till the absorbance at 280 $\mathrm{nm}$ comes to zero. The bound lectin was eluted with $100 \mathrm{mM}$ glycine- $\mathrm{HCl}$ buffer, $\mathrm{pH} 2.5$. The eluted fractions were immediately neutralized with $2 \mathrm{M}$ Tris-HCl-buffer $\mathrm{pH}, 8.3$. The fractions showing agglutination activity were pooled and dialyzed against equilibration buffer in order to remove Tris ions which may interfere in protein estimation.

Protein and carbohydrate content estimation. Protein concentration in the crude as well as purified lectin preparation was estimated by the method of Lowry et al., 1951 using lipid-free BSA as the standard. The carbohydrate content of AJL was determined by anthrone method using D-glucose as standard (Spiro, 1966).

Polyacrylamide gel electrophoresis. Electrophoretic analysis of purified native protein was performed under alkaline conditions $\mathrm{pH}$ 8.3 in $10 \%(\mathrm{w} / \mathrm{v})$ polyacrylamide gel according to the method of Davis, 1964 and $7.5 \%(\mathrm{w} / \mathrm{v})$ gel was used to carry out acidic PAGE at $\mathrm{pH} 4.5$ by the method of Reisfeld et al., 1962 For denaturing PAGE (SDS-PAGE) the method described by Laemmli, 1970 was followed using $11 \%(\mathrm{w} / \mathrm{v})$ separating gel. Electrophoresis was carried out at constant voltage $(100 \mathrm{~V})$ for $4-5 \mathrm{~h}$ in a Pharmacia electrophoresis apparatus. After electrophoresis the gels were stained with $0.1 \%$ Coomassie Brilliant blue (R 250) prepared in destaining solution $(1: 3: 6$ acetic acid : methanol : water $\mathrm{v} / \mathrm{v})$.

Isoelectric focusing. Affinity purified A. jacquemontii lectin was subjected to isoelectric focusing in $5 \%$ polyacrylamide tube gel using carrier ampholines having $\mathrm{pH}$ range 3.5 to 9.5 according to Robertson et al., 1987. A set of $\mathrm{pI}$ markers was also loaded onto the separate tube gel. Before staining ampholines were eluted from the gels by incubation in $10 \%$ trichloroacetic acid (TCA) for $10 \mathrm{~min}$ followed by $1 \% \mathrm{TCA}$ for $30 \mathrm{~min}$ at room temperature (Bollag, 1996). The gels were stained with $0.1 \%$ Coomassie Brilliant blue (R 250) as explained before. Isoelectric point was calculated by comparing the mobility of lectin with that of $\mathrm{pI}$ markers.

Gel-exclusion chromatography. The molecular mass of the native lectin was determined by gel filtration chromatography on Biogel
P-200 column $(1.6 \times 67 \mathrm{~cm})$ calibrated with molecular weight markers in the range of $12.4 \mathrm{kDa}$ to $66 \mathrm{kDa}$ according to the method of Andrews, 1964. The column was equilibrated and eluted with $10 \mathrm{mM}$ PBS, pH 7.2.

pH and thermal stability. As the bound lectin was desorbed from the affinity matrix by employing glycine- $\mathrm{HCl}$ buffer, $\mathrm{pH} 2.5$ the effect of such a low $\mathrm{pH}$ on lectin-induced hemagglutination was ascertained before standardizing the purification protocol. The lectin sample was incubated with the above-mentioned buffer for time intervals ranging from $15 \mathrm{~min}$ to $6 \mathrm{~h}$ followed by neutralization with Tris-HCl buffer, $\mathrm{pH}$ 8.3. Thereafter, titer of each treated sample was compared with that of controls i.e. lectin sample mixed with glycine- $\mathrm{HCl}$ followed by immediate neutralization and lectin sample in PBS alone. The agglutination titer obtained by assaying the lectin using $10 \mathrm{mM}$ PBS was considered $100 \%$. For checking thermal stability $1 \mathrm{ml}(1 \mathrm{mg} / \mathrm{ml})$ lectin in $10 \mathrm{mM}$ PBS was heated in a water bath for $30 \mathrm{~min}$ at a defined temperature in the range 40$100^{\circ} \mathrm{C}$ and cooled to room temperature. The inactivation kinetics of the protein was performed using serially diluted $30 \mu$ lectin with an equal amount of PBS and performing hemagglutination assay as explained above. Lectin sample without heating served to estimate as control, which was considered to be $100 \%$ activity.

Effect of detergents and metal ions on lectin-induced hemagglutination. The effect of three denaturing agents i.e. urea, thiourea and guanidine- $\mathrm{HCl}$ at a concentration range of 0.5-8.0 M in PBS was ascertained on lectin activity by incubating $30 \mathrm{ml}$ of each denaturant solution with an equal volume of $\mathrm{AJL}$ at $37^{\circ} \mathrm{C}$ for $1 \mathrm{~h}$. Lectin sample in PBS served to estimate as control which was considered to be $100 \%$ activity. To examine divalent cation requirement of AJL for hemagglutination demetallization of purified lectin was carried out by the method of Paulova et al., 1971 by using $0.1 \mathrm{M}$ EDTA followed by remetallization of a part of the sample with $0.1 \mathrm{M} \mathrm{CaCl}_{2}$ and $\mathrm{MnCl}_{2}$. Following these treatments hemagglutination assay was carried out with each sample and titer was compared with that of respective untreated samples.

Atomic absorption spectrophotometry. The affinity purified lectin was examined for the presence of various divalent metal ions i.e. $\mathrm{Ca}^{2+}, \mathrm{Co}^{2+}, \mathrm{Cr}^{2+}, \mathrm{Cu}^{2+}, \mathrm{Fe}^{2+}, \mathrm{Mn}^{2+}, \mathrm{Ni}^{2+}, \mathrm{Zn}^{2+}$ by Atomic absorption spectrophotometer (Shimadzu model AA6200) using an air-acetylene flame. The lectin sample was digested in the presence of a mixture of concentrated $\mathrm{HNO}_{3}$ and $\mathrm{HClO}_{4}(1: 1)$ for $30 \mathrm{~min}$. Prior to analysis the digested lectin sample was extensively dialyzed against deionized water to remove any ions. Standards were made by diluting commercial stock solutions of the respective metals.

Anti-insect activity. Effect of AJL on development of melon fruit fly Bactrocera cucurbitae along with its effect on the activity of some of the hydrolytic enzymes was studied.

Insect bioassay: About 100 gravid females were released in mesh cages having fresh pumpkin pieces for 8 hours and these charged pumpkin pieces were dissected in saline water for harvesting the larvae (64-72 h). AJL at concentrations of 10, 20, 40, 80 and 160 $\mathrm{mg} / \mathrm{ml}$ was incorporated in artificial diet prepared according to the method described by Srivastava, 1975. Diet was poured into glass 
vials ( $25 \mathrm{~mm}$ O.D $\times 100 \mathrm{~mm}$ Length) using seven replicas for each concentration as well as for control. Ten second instar larvae (64$72 \mathrm{~h}$ old) were released into each vial and kept in culture room/ B.O.D. incubator. Daily observations were made for pupation and emergence. The data was calculated for larval period, pupal period, total developmental period, percentage pupation, percentage emergence and lethal dose $\left(\mathrm{LC}_{50}\right)$.

Biochemical analysis: The second instar (64-72 h) larvae were released on both the treated and control diet for periods of 24, 48 and $72 \mathrm{~h}$. Sub-lethal dose of AJL calculated on the basis of morphogenetic studies was used for these biochemical estimations. The larvae were harvested after specified treatment period and were assayed for activity of three hydrolytic enzymes i.e. Esterases, Acid and Alkaline Phosphatases involved in digestion, development, growth, metamorphosis and detoxification. The standard methods available in literature were applied for estimation of various enzymes on the fresh weight basis by taking about 10 larvae for preparing the required concentration of homogenate. There were six replications for each experiment. The methodology given by Katzenellenbogen and Kafatos, 1971 was followed for extraction and estimation of Esterase. Phosphatases activity (Acid and Alkaline) was determined by following the method given by Mc Intyre, 1971

Statistical analysis: The results were expressed as the mean \pm S.E. The data were compared using one-way analysis of variance (ANOVA) and student's-t-test to know the significance of the results obtained. The data were subjected to probit analysis to ascertain the $\mathrm{LC}_{50}$ value of $\mathrm{AJL}$. All these tests were carried out with the help of SPSS computer program.

Evaluation of in vitro anti-proliferative activity of AJL against human cancer cell lines. The inhibitory potential of AJL against 13 human cancer cell lines such as MCF-7 (breast), SKOV-3 (ovary), SiHa (cervix), PC-3 (prostrate), SNB-78 (CNS), IMR-32 (neuroblastoma), Colo-205 (colon), HT-29 (colon), HCT-15 (colon), SW-620 (colon), HEP-2 (liver), HOP-62 (lung) and A-549 (lung) was checked using a high-flux anticancer drug screening pilot scale method by Monks et al., 1991. The cell lines were maintained in RPMI-1640 medium supplemented with 10\% FCS at $37^{\circ} \mathrm{C} 5 \%$ carbon dioxide and $90 \%$ relative humidity in carbon dioxide incubator (Heraeus). The cells at a subconfluent stage were harvested by treatment with trypsin and single cell suspension made in the above mentioned medium. An aliquot of $100 \mathrm{ml}$ of cell suspension $(1,00000$ cells $/ \mathrm{ml})$ was added to each well of 96 well plates and plates were incubated for $24 \mathrm{~h}$ in carbon dioxide incubator maintained at the above-mentioned conditions. Subsequently, the lectin solution which was prepared in PBS, pH 7.2 was added in concentration ranging between $30-100 \mu \mathrm{g} / \mathrm{ml}$ and the culture was incubated for an additional $48 \mathrm{~h}$. The adherent cell cultures were fixed in situ by adding $50 \mathrm{ml}$ of $50 \%(\mathrm{w} / \mathrm{v})$ trichloroacetic acid (final concentration $10 \% \mathrm{TCA}$ ) and incubated for $1 \mathrm{~h}$ at $4^{\circ} \mathrm{C}$. The supernatant was discarded and plates were washed five times with deionized water and dried. $100 \mathrm{ml}$ of sulforhodamine B (SRB 0.4 $\mathrm{w} / \mathrm{v}$ in $1 \%$ acetic acid) was added to each well and the culture was incubated for $10 \mathrm{~min}$ at room temperature. The unbound SRB was removed by washing five times with $1 \%$ acetic acid and the plates were air-dried. The dye bound to basic amino acids of the cell membrane was solubilized with Tris buffer (10 mM, pH 10.5) and the absorption was measured at $540 \mathrm{~nm}$ by ELISA reader (Multiscan EX Labsystem) to determine the relative cell growth or viability in the treated as well as untreated cells. The standard anticancer drugs viz. 5-flurouracil, mytomycin $\mathrm{C}$ and paclitaxel at a concentration of $1 \times 10^{-5} \mathrm{M}$ were used as positive controls.

\section{Results and Discussion}

Isolation and molecular properties. A monocot lectin having potent anti-insect and anti-proliferative activity was purified from the tubers of a wild Himalayan cobra lily Arisaema jacquemontii Blume and was designated $A$. jacquemontii lectin (AJL). Dialyzed crude extract was directly loaded on the affinity column as explained in materials and methods. AJL was eluted as a single peak (Fig. 1) with 100 $\mathrm{mM}$ glycine- $\mathrm{HCl}$ buffer, $\mathrm{pH}$ 2.5. The complete absence of lectin activity in $10 \mathrm{mM}$ phosphate buffered saline unadsorbed fractions shows the suitability of the matrix for the lectin. As reported earlier for other araceous lectins, the low purification fold of AJL indicates the high lectin content of the total extractable proteins present in the storage tissues (Van Damme et al., 1995). The crude extract from 100 grams of tuber contained $704 \mathrm{mg}$ total protein with a total activity of 16,000 AU. The specific activity of AJL in the crude extract was $22.7 \mathrm{AU} / \mathrm{mg}$. The AJL fraction recovered from the affinity purification column contained $114 \mathrm{mg}$ protein with a specific activity of $87.2 \mathrm{AU} / \mathrm{mg}$, representing a $62 \%$ recovery of the AJL activity and 3.8-fold purification. Affinity purified lectin exhibited an apparent molecular mass of $52 \mathrm{kDa}$ as determined by gel filtration chromatography. In SDS-PAGE at

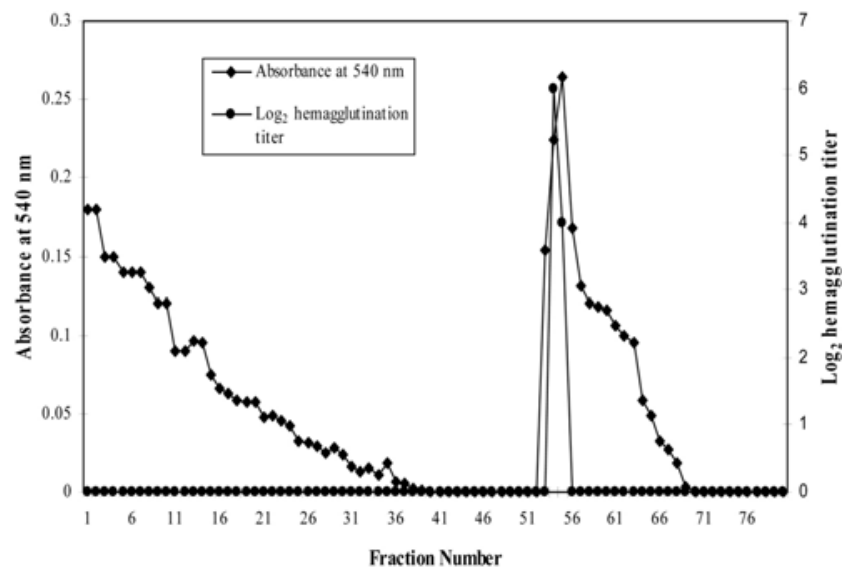

Fig. 1. Affinity purification of AJL from tuber extract on asialofetuin-linked amino activated silica beads. Crude dialyzed extract of AJL was applied to the column $(0.8 \times 6.0 \mathrm{~cm})$ preequilibrated with $10 \mathrm{mM}$ PBS, $\mathrm{pH}$ 7.2. Bound lectin was eluted (fraction size- $2 \mathrm{ml}$ ) with $100 \mathrm{mM}$ glycine- $\mathrm{HCl}, \mathrm{pH} 2.5$ at flow rate $30 \mathrm{ml} / \mathrm{h}$. Absorbance values of the complex formed in protein estimation by Lowry et al. (1951) at $540 \mathrm{~nm}$ are given by the solid diamonds and $\log _{2}$ hemagglutination titre, determined using $2 \%$ suspension of rabbit erythrocytes, is given by the solid circles. 


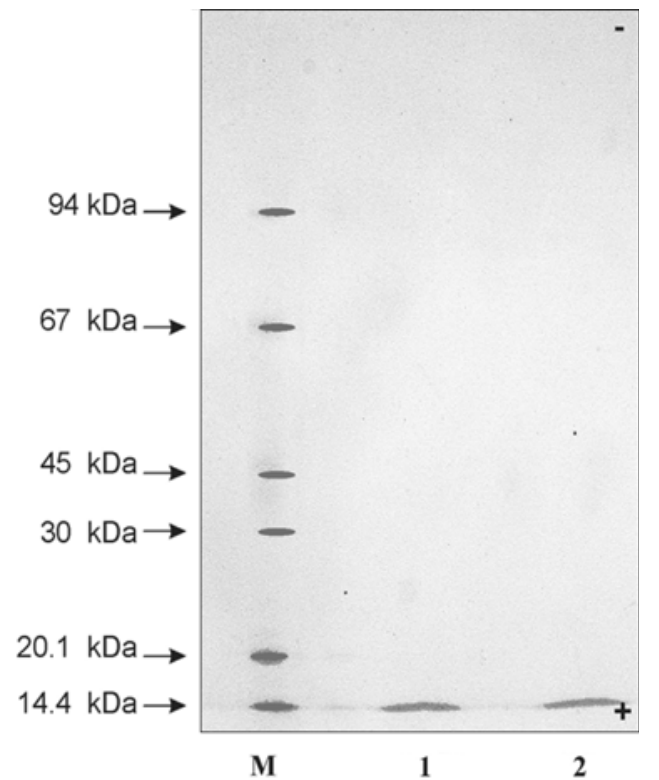

Fig. 2. SDS-PAGE of AJL at $\mathrm{pH} 8.3$ using $11 \%$ gel in the presence of $2 \% \quad \beta$-mercaptoethanol (running time $4 \mathrm{~h}$ at a constant $150 \mathrm{~V}$ ). $40 \mu \mathrm{g}$ protein was loaded. Molecular mass markers (lane M) from top to bottom are: phosphorylase $\beta$ (94 $\mathrm{kDa})$, albumin bovine $(67 \mathrm{kDa})$, ovalbumin $(45 \mathrm{kDa})$, carbonic anhydrase $(30 \mathrm{kDA})$, trypsin inhibitor $(20.1 \mathrm{kDa})$ and $\alpha$-lactalbumin $(14.4 \mathrm{kDa})$. Lane 1 and 2 represent the electrophoresis with and without $\beta$-mercaptoethanol.

pH 8.3, AJL gave a single band with a subunit molecular mass of $13.4 \mathrm{kDa}$ under reducing and non-reducing conditions (Fig. 2) indicating the tetrameric nature of AJL. The lectins from other monocotyledonous families such as amaryllidaceae and orchidaceae (Barre et al., 1996) also show similar subunit structure indicating the evolutionary closeness. Further, similar results obtained in SDS-PAGE both under reducing as well as non-reducing conditions showed the absence of disulphide linkages among various subunits. This finding is further supported by the fact that most of the araceous lectins lack cysteine residues in their amino acid composition. These results corroborate with earlier findings on lectins from this family (Shangary et al., 1995). Thus araceous monocot lectins are different from other monocot lectins especially from family graminae which contain high content of cysteine (Tabary et al., 1987). Native PAGE of AJL under acidic conditions showed a single band (Fig. 3A) while under basic conditions two bands were obtained (Fig. 3B). In isoelectric focusing AJL showed multiple bands in the pI zone 4.6-5.5 (Fig. 3C) thus suggesting the presence of charged isomers in the affinity purified lectin preparation. These properties of AJL are in consonance with the earlier reported araceous lectins (Shangary et al., 1995, Kaur et al., 2005, Kaur et al., 2006) and some other monocot lectins (Van Damme et al., 1992; Barre et al., 1996). The charge microheterogeneity could be genetic in origin as observed in lectins from family

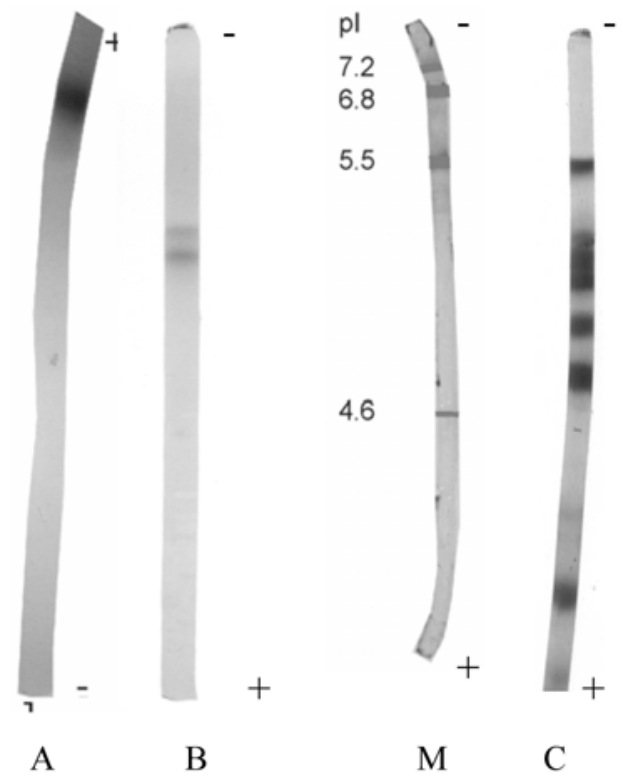

Fig. 3. (A) Discontinuous PAGE of AJL at $\mathrm{pH} 4.5$ using $7.5 \%$ gel (running time $8 \mathrm{~h}$ at constant $150 \mathrm{~V}$ ). $80 \mu \mathrm{g}$ protein loaded on each tube gel. (B) Discontinuous PAGE at pH 8.3 using 10\% gel (running time $8 \mathrm{~h}$ at constant $100 \mathrm{~V}$ ). $60 \mu \mathrm{g}$ protein was loaded on each tube gel. (C) Isoelectric focusing for AJL on 5\% polyacrylamide gel using carrier ampholines of pI range 3.5-10.0 (running time $12 \mathrm{~h}$ at a constant $200 \mathrm{~V}$ ). pl markers (lane M) used from top to bottom are: myoglobulin 1 (pl-7.2), myoglobin 2 (pl-6.8), carbonic anhydrase II (pl-5.5) and trypsin inhibitor (pl-4.6). Protein loaded was $40 \mu \mathrm{g}$. The gels were stained with Coomassie Brilliant blue.

Amaryllidaceae and Alliaceae (Van Damme et al., 1992) or due to heterogeneity of oligosaccharide chains (Barre et al., 1996). But in the present study, a small amount of neutral carbohydrate, $3.4 \%$, should not have a large effect on charge microheterogeneity. AJL agglutinated rabbit erythrocytes with minimal erythrocyte agglutinating protein concentration (MEAPC) value $11.5 \mathrm{mg} / \mathrm{ml}$, but was unable to agglutinate human $\mathrm{ABO}$ blood group erythrocytes even after neuraminidasetreatment.

Carbohydrate binding specificity. Among the carbohydrates tested, the lectin-induced hemagglutination was inhibited by $\mathrm{N}$-acetyl-D-lactosamine (LacNAc), a disaccharide with a minimum inhibitory sugar concentration (MIC) of $25 \mathrm{mM}$ and asialofetuin (MIC of $125 \mu \mathrm{g} / \mathrm{mL}$ ). Asialofetuin is a serum desialylated glycoprotein possessing exposed terminal $\mathrm{T}$ disaccharide and LacNAc residues. Virtually no interaction occurred with fetuin in which terminal T-disaccharide and LacNAc residues are masked by sialic acid. Based on these results, the interaction between AJL and asialofetuin was employed in affinity chromatography to purify AJL. While employing different structural components of asialofetuin (Hayes and Goldstein, 1974) separately in hemagglutination assay it was shown that binding of AJL towards asialofetuin 
was due to LacNAc (Gal- $\beta-1,4-G a l N A c)$ component as it failed to recognize the other components i.e. T- disaccharide (Gal- $\beta-1,3-G a l N A c)$ and mannose. No inhibition with mannose even at concentrations as high as $100 \mathrm{mM}$ is in good accordance with the results of the hapten inhibition assay of earlier reported araceous lectins and differs from monocot mannose-binding lectins (Shangary et al., 1995, Kaur et al., 2005, Kaur et al., 2006). This observation has also been recorded in case of Xanthomonas saggitifolium lectin which is also a member from the family Araceae having no affinity for D-mannose (MO et al., 1999).

The other sugar/derivatives and glycoproteins were noninhibitory towards the lectin. Earlier reported lectins from Arisaema intermedium A. wallichianum (Kaur et al., 2005), A. tortuosum (Dhunna et al., 2005) and A. helleborifolium (Kaur et al., 2006) were reported to have specificity for N-acetyl-Dlactosamine (LacNAc) also as reported in the present study. The isolation of LacNAc specific lectins from genus Arisaema assumes significance as a biological tool because earlier it has been reported in the literature that LacNAc is one of the important cancer marker (Green et al., 1988).

pH and thermal stability. This lectin was found to be stable at $\mathrm{pH} 2.5$ for $2 \mathrm{~h}$. This proves the reliability of the purification protocol used in which the lectin was exposed to $\mathrm{pH} 2.5$ for a very brief period followed by immediate neutralization. The results of heat denaturation showed that $A$. jacquemontii lectin was stable up to $60^{\circ} \mathrm{C}$ and its hemagglutination activity starts declining afterwards. However AJL retained $25 \%$ of its residual activity even after boiling for $15 \mathrm{~min}$.

Effect of denaturants and metal ions. Urea and guanidine$\mathrm{HCl}$ at $3.0 \mathrm{M}$ concentration while thiourea at $4.0 \mathrm{M}$ reduced the lectin activity to $50 \%$. The denaturation by these agents indicates the globular nature of lectins stabilized mainly by hydrogen bonding and hydrophobic interactions (Nelson and Cox, 2001).

EDTA treatment or addition of metal cations showed no effect on lectin activity suggesting that either the lectin activity was not dependent on metal cations or these metal ions are too strongly held in lectin structure and cannot be removed by dialysis. To check this further atomic absorption spectroscopy was used to examine the presence/absence of various divalent metal ions. Out of various metal ions tested, $\mathrm{Co}^{2+}$ and $\mathrm{Zn}^{2+}$ were present at a conc. of 0.003 and 0.002 mole per mole of AJL subunit $(13.4 \mathrm{kDa})$. Thus these metal ions represent a small fraction of divalent metal ions in lectin protein, which might suggest adventitious metal ion binding. This finding is contrary to the work on dicot lectins which possess divalent cations, that are a part of structure and can be removed on dialysis against EDTA thus affecting their activity (Sharon and Lis, 1990) but resemble to that of lectin from Arisaema helleborifolium (Kaur et al., 2006).

Anti-insect activity. A perusal of literature indicates that some plant lectins belonging to varied sugar specificities i.e. mannose specific mannose/glucose specific, galactose specific and $\mathrm{N}$-acetyl-D-galactosamine specific have shown entomotoxic effects when fed to insects from Coleoptera, Homoptera and Lepidoptera. Some genes encoding for entomotoxic lectins have been introduced into different crops rendering the transgenic plants less susceptible to the attack of insects (Carlini and Grossi-de-sa, 2002). Further mannose-binding monocot lectins having tetrameric structure show more potent insecticidal property and antifungal activity than the dimeric or trimeric lectins because of their ability to interact strongly with complex glycoconjugates due to their multivalency (Barre et al., 1996). AJL having a similar structure but with different sugar specificity needs to be investigated in this regard.

Artificial diet bioassay: In the present study, the influence of AJL was demonstrated in significant prolongation of larval period, pupal period and thus in the total development period of this dipteran tephritid fruit fly (B. cucurbitae). Larval period showed an increase of 2.28 days i.e. 7.77 days in control to 10.05 days at $80 \mu \mathrm{g} / \mathrm{ml}$. Pupal period increased from 9.57 days in control to 10.74 days at $80 \mu \mathrm{g} / \mathrm{ml}$ i.e. increase of 1.17 days. Thus the total development period increased by 3.45 days (Table). The percentage pupation and

Table 1. Larval period, pupal period, total development period, percentage pupation and percentage emergence of second instar larvae (64-72 h) of B. cucurbitae after treatment with AJL

\begin{tabular}{cccccc}
\hline $\begin{array}{c}\text { Concentration } \\
(\mu \mathrm{g} / \mathrm{ml})\end{array}$ & $\begin{array}{c}\text { Larval period } \\
\text { (in days) } \\
\text { (Mean } \pm \text { S.E.) }\end{array}$ & $\begin{array}{c}\text { Pupal period } \\
\text { (in days) } \\
\text { (Mean } \pm \text { S.E.) }\end{array}$ & $\begin{array}{c}\text { Total Development } \\
\text { Period (in days) } \\
\text { (Mean } \pm \text { S.E.) }\end{array}$ & $\begin{array}{c}\text { Percentage pupation } \\
\text { (in days) } \\
\text { (Mean } \pm \text { S.E.) }\end{array}$ & $\begin{array}{c}\text { Percentage } \\
\text { emergence (in days) } \\
\text { (Mean } \pm \text { S.E.) }\end{array}$ \\
\hline $\begin{array}{c}\text { Control } \\
10\end{array}$ & $7.8 \pm 0.2$ & $9.6 \pm 0.2$ & $17.3 \pm 0.1$ & $67 \pm 2$ & $53 \pm 2$ \\
20 & $8.8 \pm 0.1$ & $9.7 \pm 0.2$ & $18.5 \pm 0.2$ & $56 \pm 6$ & $41 \pm 4$ \\
40 & $9.2 \pm 0.2$ & $9.9 \pm 0.2$ & $19.0 \pm 0.4$ & $41 \pm 1$ & $32 \pm 4$ \\
80 & $9.5 \pm 0.2$ & $10.4 \pm 0.2$ & $19.9 \pm 0.2$ & $33 \pm 3$ & $27 \pm 2$ \\
160 & $10.1 \pm 0.2$ & $10.7 \pm 0.2$ & $20.9 \pm 0.2$ & $24 \pm 3$ & $14 \pm 2$ \\
F-value & $10.1 \pm 0.3$ & 0 & 0 & $16 \pm 2$ & 0 \\
\hline
\end{tabular}

*significant at $1 \%, * *$ significant at $5 \%$. 
percentage emergence was also deleteriously and significantly affected $(p<0.01)$. As can be seen from table, the percentage pupation declined from $67.14 \%$ in control to $24.29 \%$ at $80 \mu \mathrm{g} /$ $\mathrm{ml}$. The percentage emergence also showed a sharp decline in dose dependent manner being only $14.29 \%$ at $80 \mu \mathrm{g} / \mathrm{ml}$ as compared to control $(53.06 \%)$ whereas there was no emergence at the $160 \mu \mathrm{g} / \mathrm{ml}$. Moreover the adult flies released from the treated pupae died in the pre-reproductive stage. The $\mathrm{LC}_{50}$ calculated on the basis of adult emergence was $34 \mu \mathrm{g} / \mathrm{ml}$. The significance of the present study lies in the fact that AJL had a marked effect on the growth and survival rate of the insect at a comparative lower doses indicating the possibility of using this lectin in a biotechnological strategy for insect pest management of cucurbits.

Inhibition of enzyme activity: This study was further carried out to investigate the effect of AJL on various hydrolytic enzymes generally involved in digestion, development and metabolism i.e. Esterases, Acid Phosphatases (AcP) and Alkaline phosphates (AkP). The esterases showed a decrease as the larvae developed further from second instars. Then it increased when they had reached the age of $144 \mathrm{~h}$ during the normal course of development. However the esterase activity increased in the treated larvae after 48 and $72 \mathrm{~h}$ of treatment and the increase was significantly high as compared to the control of the same age group of the larvae (Fig. 4A) Acid Phosphatases (AcP) activity increased during the normal development of B. cucurbitae larvae whereas AkP showed a continuous decrease after $96 \mathrm{~h}$ of age. But the treatment of larvae with AJL resulted in suppression of both the enzymes when compared with the controls of the same age group (Fig. 4 B,C). The role of esterases in development of resistance and in sequestration of xenobiotics has already been established (Devorshak and Roe, 1999; Rup et al., 1999). The increase in the plateau of esterase activity in the lectin treated larvae suggest that esterases might be playing a significant role in detoxification of $A$. jacquemontii lectin and the increase in activity could be attributed to positive feedback response. The suppression of other two hydrolases (Acid and Alkaline Phosphatases) indicated that both Acid and Alkaline Phosphatases play no role in the detoxification of lectin from AJL in B. cucurbitae and that lectin might be interfering in the feedback biomechanism of these enzymes during their synthesis.

In most countries where B. cucurbitae is present farmers frequently spray broad-spectrum insecticides to control the pest. The phytosensitive nature of cucurbits further defies chemical control. In the absence of more specific active ingredients for chemical control against tephritids there is a need to find some suitable method to control these insect pests. The results of the study presented here indicate that AJL may act as more specific biodegradable active ingredient in the management of this insect pest but it may require further studies.

Anti-proliferative activity. The in vitro anti-proliferative activity of AJL was evaluated against thirteen human cancer
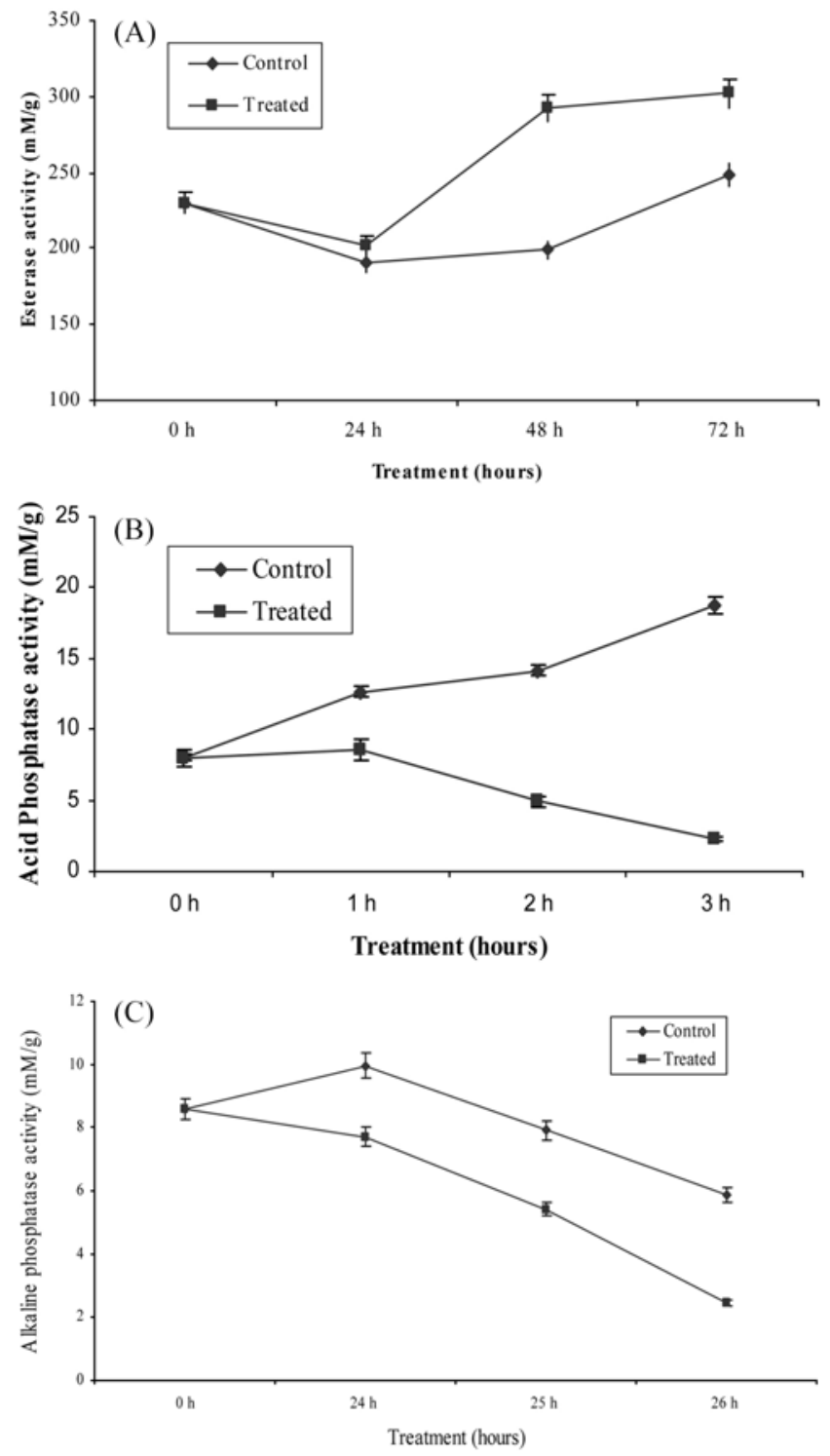

Fig. 4. Effect of AJL added into artificial diet on activity of various enzymes i.e. Esterase (Fig. 4A) Acid Phosphatases (Fig. 4B) and Alkaline Phosphatases (Fig. 4C) of Bactrocera cucurbitae at various time intervals. The treatment was given for $0 \mathrm{~h}$ (64-72 h age), $24 \mathrm{~h}$ (88-96 h age), $48 \mathrm{~h}$ (112-120 h age) and $72 \mathrm{~h}$ (136-144 h age).

cell lines representing different organs and tissues using a pilot scale in vitro anticancer screening method as described in materials and methods. A. jacquemontii lectin was found to have appreciable inhibitory effect on the in vitro proliferation of HCT-15 (82\%), HOP-62 (77\%), SW-620 (73\%) and HT-29 $(70 \%)$ cancer cell lines (Fig. 5) at a concentration of $100 \mathrm{mg} /$ $\mathrm{ml}$. Out of the other cell lines employed in Sulphorhodamine B (SRB) assay AJL showed a mild inhibitory effect on the proliferation of IMR-32 (41\%), SKOV-3 (41\%), Colo-205 (37\%), PC-3 (29\%), HEP-2 (21\%), A-549 (21\%) while it fail to restrict the proliferation of SiHa, MCF-7 and SNB-78. Out 


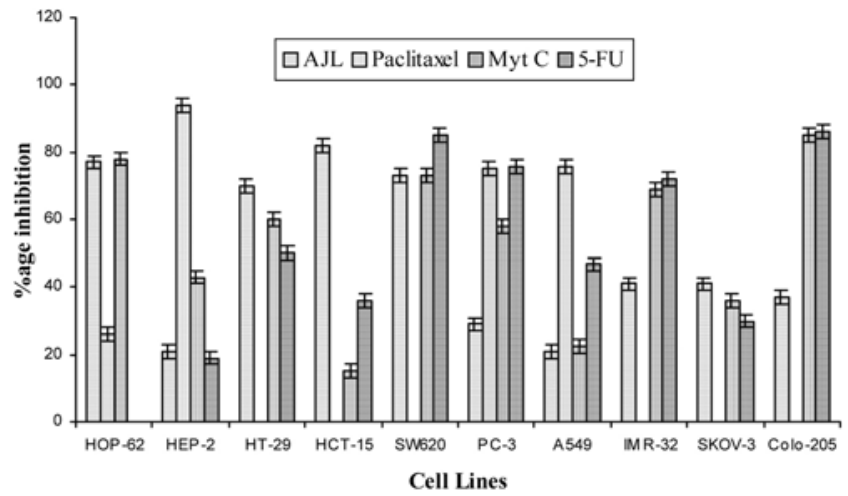

Fig. 5. Histogram showing percentage inhibition of human cancer cell lines with AJL at a concentration of $100 \mu \mathrm{g} / \mathrm{mL}$. (Mytomycin C Paclitaxel and 5-fluorouracil were used as standards at a dose of $\left.1 \times 10^{-5} \mathrm{M}\right)$.

of already reported Arisaema lectins in literature $A$. intermedium lectin inhibited in vitro proliferation of PC-3 (30.80\%), A-549 (19.02\%) and SiHa (27.96) (Kaur et al., 2005). Lectin from $A$. helleborifolium showed an inhibitory effect on the proliferation of HOP-62 (95\%) and HCT-15 (92\%) (Kaur et al., 2006) While in case of $A$. tortuosum lectin $49 \%$ inhibition was recorded in case of $\mathrm{SiHa}$ and $40 \%$ in case of HT-29 cell lines (Dhunna et al., 2005).

As aberrant glycosylation is a hallmark of malignancy and some products are truly tumor-specific antigens that have not been found in normal tissue (Abdullaev and Mejia, 1997), the variation of proliferation inhibition on different cell-lines may be due to the presence of glycoconjugates varying slightly in their activity thus leading to different signaling action of lectins. As every lectin has unique fine sugar specificity there is a need to check a range of lectins against a number of cancer cell-lines. The present results on the inhibitory potential of AJL are in line with the earlier reports on a few commercially available phytolectins such as ConA, WGA and lectin from Agaricus bisporus tested on various cancer cell lines. Additional studies are required to understand the exact mechanisms of the antiproliferative effect of plant lectins and future examinations should be focused on these possibilities in appropriate models of human diseases and it is also possible that what other agents (e.g. synthetic compounds) should interact with plant lectins in a synergistic manner to prevent cancer and make a better prediction to which type of protocol (e.g. chemopreventive or chemotherapeutic) for the anti-proliferative effect of plant lectins is most likely to be successful both in the animal model and ultimately in human diseases.

In conclusion, a lectin was isolated and characterized from tubers of $A$. jacquemontii, which has shown promising antiinsect and anti-cancer activities. Thus AJL because of these properties can be a useful tool in cancer research, glycobiology and pest management.
Acknowledgments This work was supported by a research grant from the CSIR. Miss Manpreet and Mr. Kuljinder Singh are recipients of Senior Research Fellowship from CSIR, New Delhi, India. We are also thankful to sophisticated instrumentation research center Punjab University, Chandigarh to carry out metal ion analysis.

\section{References}

Abdullaev, F. I. and de Mejia, E. G. (1997) Antitumor effects of plant lectins. Nat. Toxins 5, 157-163.

Andrews, P. (1964) Estimation of the molecular weights of proteins by Sephadex gel filtration. Biochem. J. 91, 222-223.

Barre, A., Van Damme, E. J., Peumans, W. J. and Rouge, P. (1996) Structure-function relationship of monocot mannosebinding lectins. Plant Physiol. 112, 1531- 1540.

Bollag, D. M., Rozycki, M. D. and Edelstein S. J. (1996) Isoelectric focusing in: Protein Methods, pp. 173-185, John wiley \& Sons Inc., New York, USA.

Candy, L., Van Damme, E. J. M., Peumans, W. J., MenuBouaouiche, L., Erard, M. and Rouge, P. (2003) Structural and functional characterization of the GalNAc/Gal-specific lectin from the phytopathogenic ascomycete Sclerotinia sclerotiorum (Lib.). Biochem. Biophys. Res. Commun. 308, 396-402.

Carlini, C. R. and Grossi-de-Sa, M. F. (2002) Plant toxic proteins with insecticidal properties. A review on their potentialities as bioinsecticides. Toxicon 40, 1515-1539.

Davis, B. J. (1964) Disc electrophoresis. II. Methods and applications to human serum proteins. Ann. New York Acad Sci. 121, 404427.

Devorshak, C. and Roe, R. M. (1999) The role of esterase in insecticide resistance. Reviews in Toxicology 2, 501-537.

Eisemann, C. H., Donaldson, R. A., Pearson, R. D, ,Cadogan, L. C., Vuocolo, T. and Tellam, R. L. (1994) Larvicidal activity of lectins on Lucilio cuprina: Mechanism of action. J. Entomol. Exp. Appl. 7, 1-10.

Green, E. D., Adelt, G., Baenziger, J. U. ,Wilson, S. and Van Halbeek, H. (1988) Th asparagine-linked oligosaccharides on bovine fetuin. Structural analysis of $\mathrm{N}$ - glycanase-released oligosaccharides by 500 -megahertz $1 \mathrm{H}$ NMR spectroscopy. $J$. Biol. Chem. 263, 18253-18268.

Gupta, J. N,. Verma, A. N. and Kashyap, R. K. (1978) An improved method for mass rearing of melon fruit fly Dacus cucurbitae Coquillett. Indian J. Entomol. 40, 470-471.

Hayes, C. E. and Goldstein, I. J. (1974) An b-D-Galactosylbinding lectin from Banderiaea simplicifolia seeds. J. Biol. Chem. 249, 1904-1914.

Katzenellenbogen, B. and Kafatos, F. C. (1971) General esterases of silkmoth moulting fluid: Preliminary characterization. $J$. Insect Physiol. 17, 1139-1151.

Kaur, M., Singh, J., Kamboj, S. S., Singh, J., Kaur, A., Sood, S. K. and Saxena, A. K. (2005) Isolation and characterization of two N-acetyl-D-lactosamine specific lectins from tubers of Arisaema intermedium Blume and A. wallichianum Hook $\mathrm{f}$. Indian J. Biochem. Biophys. 42, 34-40.

Kaur, M., Singh, K., Rup, P. J., Saxena, A. K., Khan, R. H., 
Ashraf, M. T., Kamboj, S. S. and Singh, J. (2006) A tuber lectin from Arisaema helleborifolium Schott with anti-insect activity against melon fruit fly Bactrocera cucurbitae (Coquillett) and anti-cancer effect on human cancer cell lines. Arch. Biochem. Biophys. 445, 156-165.

Kawagishi, H., Nomura, A., Mizuno, T., Kimura, A. and Chiba, S. (1990) Isolation and characterization of a lectin from Grifola frondosa fruiting bodies. Biochim. Biophys. Acta 1034, 247252.

Laemmli, U. K. (1970) Cleavage of structural proteins during the assembly of the head of bacteriophage T4. Nature 277, 680685.

Lin, J. Y. and Chou, T. B. (1984) Isolation and characterization of a lectin from edible mushroom Volvariella volvacea. $J$. Biochem. (Tokyo) 96, 35-40.

Lowry, O. H., Rosebrough, N. J., Farr, A. R. and Randall, R. J. (1951) Protein measurements with folin-phenol reagent. J. Biol. Chem. 193, 265-275.

MC Intyre, R.J. (1971) A method for measuring activities of acid phosphatases separated by acrylamide gel electrophoresis. Biochem. Genet. 5, 45-50.

MO, H., Evers, K. G., Winter, D. L., Peumans, W. J. and Van Damme, E. J. M. (1999) Xanthosoma sagittifolium tubers contain a lectin with two different types of carbohydratebinding sites. J. Biol. Chem. 274, 33300-33305.

Monks, A., Scudiero, D., Skehan, P., Shoemaker, R., Paul, K., Vistica, D., Hose, C., Langley, J., Cronise, P., Wolff, A. V., Goodrich, M. G., Campbell, H., Mayo, J. and Boyd, M. (1991) Feasibility of a high-flux anticancer drug screen using a diverse panel of cultured human tumor cell lines. J. Nat. Can. Inst. 83, 757-766.

Nelson D. L. and Cox M. N. (2001) The three dimensional structure of proteins in: Lehninger Principles of Biochemistry, pp. 159-202, Macmillon Worth Publishers, New York, USA.

Paulova, M., Entlicher, G., Ticha, M., Kostir, J. V. and Kocourek, J. (1971) Studies of phytohemagglutinins.VII. Effect of $\mathrm{Mn}^{2+}$ and $\mathrm{Ca}^{2+}$ on hemagglutination of phytohemagglutinin of Pisum sativum L. Biochem. Biophys. Acta 237, 513-518.
Peumans, W. J. and Van Damme, E. J. M. (1995) Lectins as plant defence proteins. Plant Physiol. 109, 347-352.

Reisfeld, R. A., Lewis, O. J. and Williams, D. E. (1962) Disc electrophoresis of basic proteins and peptides on polyacrylamide gels. Nature 145, 281-283.

Robertson, E. F., Dannelly, H. K., Malloy, P. J. and Reeve, H. C. (1987) Rapid isoelectric focusing in a vertical polyacrylamide minigel system. Ann. Biochem. 167, 290-294.

Rup, P. J., Sohal, S. K., Dhillon, M. K., Sohi, R., Gurm, S. K., Sandhu, N., Dhingra, P., Wadha, S. K. and Kaur, G. (1999) Esterase activity in Lipaphis erysimi (Kalt) in response to seven PGRs. J. Applied Zool. Res. 10, 94-97.

Shangary, S., Singh, J., Kamboj, S. S., Kamboj, K. K. and Sandhu, R. S. (1995) Purification and properties of four monocot lectins from the family Araceae. Phytochemistry 40, 449-455.

Sharon, N. and Lis, H. (1990) Legume proteins- a large family of homologous proteins. FASEB J. 4, 3198-3208.

Spiro, R. G. (1966) Analysis of sugars found in glycoproteins. Meth. in Enzymol. 8, 3-26.

Srivastava, B. G. (1975) A chemically defined diet for Dacus cucurbitae (Coq.) larvae under aseptic conditions. Entomol. News Lett. 5, 24.

Tabary, F., Font, J. and Bourrillon, R. (1987) Isolation molecular and biological properties of a lectin from rice embryo: relationship with wheat germ agglutinin properties. Arch. Biochem. Biophys. 259, 79-88.

Van Damme, E. J. M., Goldstein, I. J., Vercammen, G., Vuylsteke, J. and Peumans, W. J. (1992) Lectins of members of the Amaryllidaceae are encoded by multigene families which show extensive homologies. Physiol. Planta 86, 245252.

Van Damme, E. J. M., Goossens, K., Smeets, K. Van Leuven, F., Verhaert, P. and Peumans, W. J. (1995) The major tuber storage protein of Araceae species is a lectin: characterization and molecular cloning of the lectin from Arum maculatum L. Plant Physiol 107, 1147-1158. 